\title{
Pubertal Food Intake and Body Length, Weight, and Composition in the Feed-Restricted Female Rat: Comparison with Well Fed Animals
}

\author{
RICHARD WILEN(45) AND FREDERICK NAFTOLIN \\ Department of Obstetrics and Gynecology, McGill University Faculty of Medicine and Royal Victoria Hospital, \\ Montreal, Quebec, Canada
}

\begin{abstract}
Summary
Individual pubertal age, food intake, and body length, weight, and composition were determined by direct measurements in 28 feed-restricted female rats studied from birth to first estrus, and were compared to well fed controls (39). The average birth $(6.87 \pm 0.19 \mathrm{~g})$ and weaning $(49.39 \pm 0.72 \mathrm{~g})$ weights of the 13 early maturing feed-restricted rats did not differ significantly from those of the 13 late maturers $(6.72 \pm 0.31 \mathrm{~g}$ and $49.96 \pm$ $1.0 \mathrm{~g}$, respectively). Mean values for all pubertal measurements are included in Table 1 . First estrus was simultaneous with vaginal opening in nine $(69 \%)$ of early and two $(15 \%)$ of the late maturing feed-restricted rats. At first estrus, the late maturing, feed-restricted animals were heavier, longer (Fig. 1), and had attained a greater quantity of total body fat, protein, and water than the early maturers. Furthermore, at first estrus the late maturing feed-restricted rats had acquired a greater proportion of body water than the early maturers; however, both groups had attained the same proportion of body protein (Fig. 2). Although early and late maturing feed-restricted rats were eating the same amounts of food at the time of vaginal opening and at first estrus, late maturing rats consumed less food per $100 \mathrm{~g}$ body wt than did early maturers. The average birth (6.99 $\pm 0.74 \mathrm{~g})$ and weaning $(49.7 \pm 0.74 \mathrm{~g})$ weights of all 29 well fed rats did not differ from those of the feed-restricted group $(6.76 \pm 0.17 \mathrm{~g}$ and $48.95 \pm 0.6 \mathrm{~g}$, respectively). First estrus was simultaneous with vaginal opening in $20(69 \%)$ of the well fed and $13(46 \%)$ of the feed-restricted rats. At first estrus average body weights and nose-rump length were the same for well fed and feed-restricted groups. Mean ages at vaginal opening and at first estrus in the feed-restricted animals were, however, greater. Absolute amount and percentage of body water did not, on the average, differ in the two groups; however, the feed-restricted animals attained less fat, were proportionately leaner, acquired a greater quantity and proportion of protein, and consumed less food.
\end{abstract}

\section{Speculation}

As seen within the previously studied well fed control group, differences in food intake and somatic development in individual feed-restricted rats at first estrus suggest that the attainment of a constant body weight, level of fat, or food intake may not be essential for the onset of puberty. Our findings in rats at first estrus suggest that although dietary manipulation may effect a change in the overall proportion of body fat and protein, within a homogeneous group of rats at first estrus there is a percentage of body protein which remains the same with increasing age at sexual maturation.

Previous studies have shown that well nourished female animals $(10,25,27,28,36,37)$ and humans (13) attain sexual maturation earlier but at an average body weight which is not statistically different from that reached by undernourished maturing individuals. Malnourished girls, however, are taller at menarche than their well fed counterparts (13). Well fed female rats may be fatter at puberty than their later maturing, undernourished controls (36). Average food intake per unit body weight is the same for well- and undernourished female rats at puberty (27). Similarly, at sexual maturation, female rats consume the same average daily calories per unit body weight whether fed a high or low fat diet ad libitum (14).

A recent report on well fed animals shows that within a group of pubertal rats, as age increases at first estrus, so do body weight, length, water, and proportion of body fat (39). Food intake per $100 \mathrm{~g}$ body wt and the percentage of body water decrease whereas the proportion of body protein remains the same with increasing age at first estrus (39).

Because of the absence of similar studies in individual underfed animals and the need to know whether the metabolic and somatic measurements taken in our well fed group at puberty (39) are affected by undernutrition, we decided to investigate the distribution of body composition, body weight, nose-rump length, and food intake in a group of pubertal female rats which had undergone restricted feeding during the postweaning immature stage of development.

\section{MATERIALS AND METHODS}

Rats (Sprague-Dawley, Charles River strain), obtained at a time at which they were pregnant for no more than 2 weeks, were individually caged in our laboratory. Temperature $\left(21^{\circ}\right)$ and light (14 hr daily) were controlled. At birth, pups were separated from their mothers and male pups were discarded. Groups of 10 female pups were placed randomly with mothers that had just given birth and had had their pups removed. Mothers were individually caged with their pups and fed Purina laboratory chow and watered ad libitum. Pups were weaned at 21 days of age and placed in individual cages. Twenty-eight pups were fed an optimal diet (42) for $5 \mathrm{hr}$ each day. This optimal diet, although considered to be low in fat by Frisch et al. (14). contains percentages of fat and protein similar to those found in Purina laboratory chow. Each pup was weighed (to the nearest $0.1 \mathrm{~g}$ ) every other day before feeding, from weaning to first estrus and on the day of vaginal opening. The food containers from which the weaned pups ate were placed in the cages each morning and removed $5 \mathrm{hr}$ later; they were weighed daily to the nearest $0.1 \mathrm{~g}$. Pubertal food intake was taken to be the average daily amount of food consumed during the $72 \mathrm{hr}$ (three meals) before first estrus or vaginal opening. Rats were observed daily, from weaning, for vaginal opening. Thereafter, vaginal smears were taken to determine first estrus (first appearance of completely cornified epithelial cells). At first estrus, rats were killed by ether anesthesia and weighed; nose-rump length was recorded with a standard sliding compass. Rats were then placed 
in individual plastic bags and immediately frozen for future body composition analysis. The frozen carcasses were chopped into small pieces and placed in tared aluminum dishes. They were dried at $95^{\circ}$ to constant weight. The weight loss was taken to equal total body water. The dried carcasses were then crushed and ground. Soxhlet extraction for a minimum of $4 \mathrm{hr}$ using petroleum ether on $5-\mathrm{g}$ portions was used to determine fat content. Two gram portions of the powdered, fat-free dry carcasses were heated with $50 \mathrm{ml} 50 \%$ sulfuric acid for 3-4 days at approximately $100^{\circ}$. The hydrolysate was quantitatively transferred to a $500-\mathrm{ml}$ volumetric flask with water and made up to volume. The total nitrogen of this solution was determined by the micro-Kjeldahl method which was corrected to protein by multiplying by a factor of $6.25(22)$. Rats were specified as early or as late maturers by using the median age at first estrus smear (53 days) as the dividing point. Two animals attained first estrus at the median age of 53 days and thus were not included in either group. The mean values for the early and late maturers were compared. Average values for the undernourished rats were compared to those of their previously reported well fed controls (39). The statistical significance of mean values and regression slopes were determined by Student $t$-test (33).

\section{RESULTS}

\section{EARLY AND LATE MATURING FEED-RESTRICTED RATS}

Of the 26 experimental animals not having first estrus on the median (53rd) day for the total population, 13 rats in which first estrus occurred before 53 days of age were specified as early maturers and 13 rats whose age at first estrus exceeded 53 days were designated as late maturers. The use of the mean day of first estrus as a dividing point resulted in an uneven distribution of early and late maturers. Despite this, the calculations for food intake and somatic variables at first estrus and at vaginal opening using the mean age at first estrus (57.8 days) as the dividing point for defining early versus late maturers yielded essentially the same findings. The average $( \pm$ SEM) birth $(6.87 \pm 0.19 \mathrm{~g})$ and weaning $(49.39 \pm 0.72 \mathrm{~g})$ weights of early maturing rats did not differ significantly from those of late maturers $(6.72 \pm 0.31$ $\mathrm{g}$ and $48.96 \pm 1.0 \mathrm{~g}$, respectively). First estrus was simultaneous with vaginal opening in nine $(69 \%)$ of the early and $2(15 \%)$ of the late maturing rats. Late maturing rats were significantly heavier and longer (Fig. 1), and had acquired a greater amount of fat, protein, and water than did the early maturers.

A comparison of previously studied well fed controls (39) shows that at first estrus the 11 late maturers had attained a
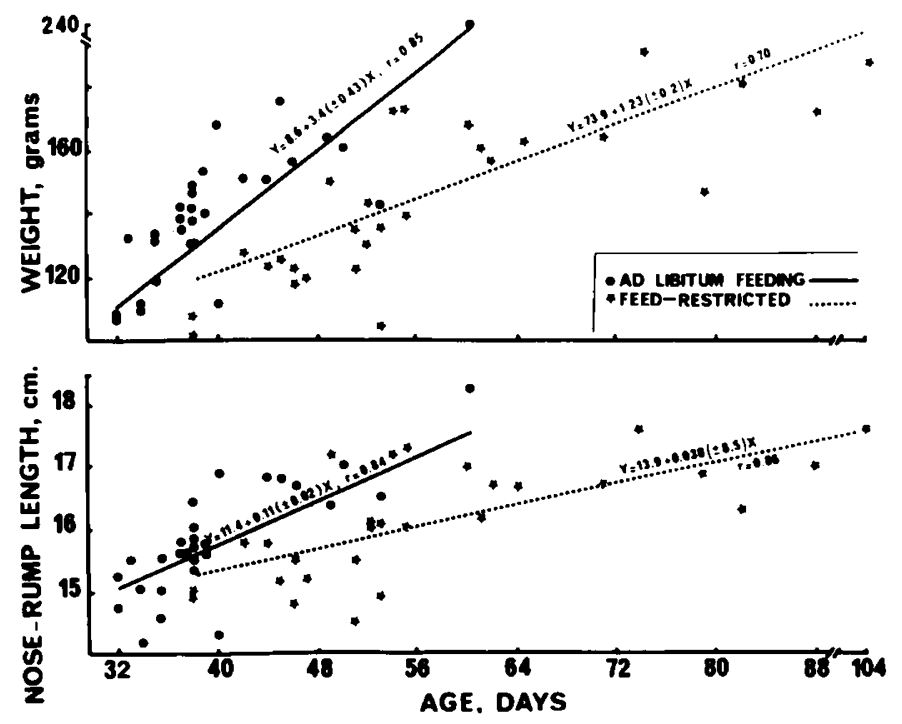

Fig. 1. Body weight and nose-rump length increases with age at first estrus $(P<0.001)$ for well fed and feed-restricted rats.

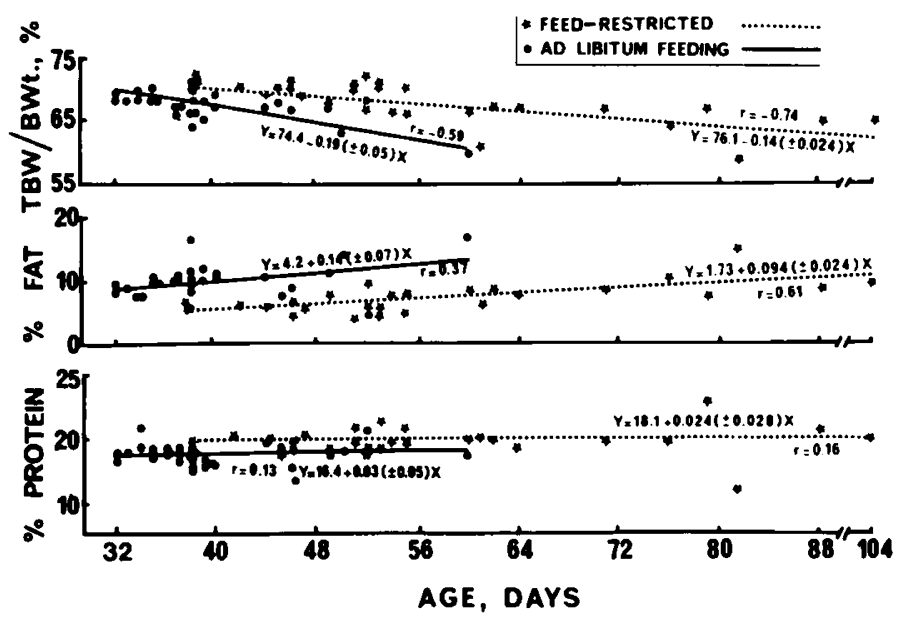

Fig. 2. Total body water (TBW)/body weight (BWt.) percentage decreases $(P<0.001)$, percent fat increases $(P<0.05)$, and percentage protein remains the same $(P>0.50)$ with increasing age at first estrus in well fed rats. TBW/BWt. percentage decreases $(P<0.001)$, percentage fat increases $(P<0.001)$, and percentage protein remains the same $(P>0.40)$ with increasing age at first estrus in feed-restricted rats.

greater amount of fat $(17.74 \pm 2.6 \mathrm{~g}, P<0.025)$ and protein $(28.5 \pm 1.95 \mathrm{~g}, P<0.01)$ than the 12 early maturers $(11.3 \pm$ $0.66 \mathrm{~g}$ and $22.36 \pm 0.92 \mathrm{~g}$, respectively).

Late maturing feed-restricted rats attained a lower percentage of total body water due to a higher proportion of acquired body fat (since percentage of fat varies inversely with percentage of body water), then the early maturers at first estrus, but both groups had the same percentage of protein (Fig. 2). Although early and late maturers ate the same average amounts of food at vaginal opening and at first estrus, late maturers consumed less food per $100 \mathrm{~g}$ body wt than did early maturers at both pubertal events.

\section{WELL FED AND FEED-RESTRICTED RATS}

The average birth $(6.99 \pm 0.74 \mathrm{~g})$ and weaning $(49.7 \pm 0.74$ g) weights of the previously reported well fed rats (39) did not differ from those of the feed-restricted $(6.76 \pm 0.17 \mathrm{~g}$ and 48.95 $\pm 0.6 \mathrm{~g}$, respectively). First estrus was simultaneous with vaginal opening in $20(69 \%)$ of the well fed and $13(46 \%)$ of the feedrestricted rats. Body weights at vaginal opening and at first estrus were the same for the well fed and feed-restricted animals. Nose-rump length and total body water did not differ in the two groups at first estrus. The feed-restricted were proportionally leaner and attained a greater proportion of body protein than the well fed animals at first estrus. At vaginal opening and at first estrus the feed-restricted group consumed a smaller quantity of food, both absolutely and relatively, on a grams per $100 \mathrm{~g}$ body wt basis.

\section{DISCUSSION}

In studies on the etiology of sexual maturation in individual subjects, the variability of food intake and somatic measurements observed within a pubertal population limits the usefulness of comparing averaged values between groups $(2,34,38,41)$. Moreover, in the case of girls, derived body composition rather than direct measurements have been employed $(2,8,15,31)$. These comparisons have, however, been the basis of the widely accepted hypothesis that the attainment of a certain body weight/composition and food or caloric intake are factors which are "critical" for the initiation of puberty $(14,16,17,27)$. Although, as is evident from the present study, comparing the averaged measurements of one pubertal group with those of another may not reliably reflect information about the individual subject at sexual maturation, these comparisons have their value 
in revealing the general effects that various experimental manipulations have on populations of pubertal individuals.

Our finding that the average well fed or feed-restricted rat reaches the same body weight at vaginal opening and at first estrus is in agreement with observations on well and underfed rats $(27)$, mice $(35,37)$, pigs (10), cattle $(25)$, and humans (13) at sexual maturation. Furthermore, it is consistent with the idea that pubertal populations of various mean ages attain the same average "demographic weight" at puberty (38).

Rapid deceleration of skeletal growth is highly correlated with pubertal onset in mammals (34). Late maturing rats (39) and girls $(13,16)$, whether well or undernourished, are longer and taller, respectively, than their early maturing controls (Table 1). This suggests a greater capacity for additional bone growth in these late maturers. Similarly, the average stature is menarche attained by a group of undernourished girls is greater than that reached by their well fed counterparts (13). In contrast to height in malnourished girls, the average pubertal nose-rump length of the feed-restricted rats is statistically the same as that attained by the well fed animals (Table 1). Unlike the situation in humans, long bone growth in rats continues well into adult life $(34,40)$. Our finding of a possible species difference in the skeletal growth of well fed or feed-restricted female rats and humans at puberty may be complicated further by the relatively greater dietary restrictions imposed on the rats as compared to the more mildly reduced nutritional intake of the malnourished girls (11).

Body composition and metabolism may be significantly affected by the pattern and/or rate at which food is ingested. When groups of postweaning immature male rats were pair-fed equal amounts of food, one group fed ad libitum and the other force-fed several meals daily ("meal-fed"), animals in the latter group became obese adults $(6,7)$. In contrast to these reports on "meal-fed" animals, the presently studied feed-restricted rats are proportionately leaner at puberty than their well fed controls. Furthermore, they also attain a greater percentage of body protein than the well fed rats at first estrus. It is not known whether the presently studied feed-restricted animals would have developed into lean or obese adults. Laboratory rats periodically nibble small quantities of food rather than gorge themselves with large amounts at one time (7). It is possible that the one 5-hr morning meal which was provided to our feedrestricted rats did not give enough time for these nocturnal animals to "over-eat and become obese" (7), or to consume as much food per unit body weight as the well fed at first estrus.
Although Kennedy and Mitra (27) showed that well fed female rats at puberty ate the same average amount of food per unit body weight as malnourished animals, the latter group was underfed before weaning and allowed to consume an unlimited quantity of food at puberty.

The lower proportion of body fat observed in the fed-restricted rats may reflect the greater availability of adipose tissue for use in maintaining energy balance $(23,24,26)$. Moreover, the increased proportion of total protein observed in these leaner feed-restricted animals suggests they may have adapted to a reduced proportion of body fat (representing a decrease in stored energy and body insulation) by increasing the "metabolic mass" (body protein) to a level sufficient to maintain basal metabolism. Interestingly, the average total body water was statistically the same in well fed and feed-restricted groups at first estrus. It is suggested that the hypothesized "demographic weight" at puberty (38) may be attained at varying proportions of body fat and protein, even though the average proportion of body water, length, and weight remain the same.

Within the feed-restricted group and within the group of previously reported well fed controls (39), the late maturing animals acquired a greater body weight, amount of body fat, protein, and water, and percentage of fat than the early maturers at first estrus (Table 1). In addition, the later maturers attained a lesser proportion of body water and ate less (per $100 \mathrm{~g}$ body wt) than the early maturers at frist estrus. Nevertheless, within well fed or feed-restricted groups at first estrus, the average percentage of body protein did not differ for the early and late maturers.

Except for the constant proportion of body protein, the changes in food intake and somatic measurements observed within groups of rats with increasing age at sexual maturation are those which would be expected in rats as they grow older $(19,26)$. Moreover, these findings are inconsistent with the hypothesized attainment of a constant body weight, level of fatness, and food or caloric intake per unit of body weight which are considered to act as a trigger for the onset of pubertal events $(14,15,27)$. Although in women, body fat may be an important factor in regulating levels of circulating estrogen, $(3,15,18,30$, 32 ), the formation of estrogen by rodent body fat has not yet been demonstrated. The role that increased levels of body fat and weight may play in the pubertal rat has been previously discussed (39).

The acquisition of a certain proportion of body protein observed in rats at all ages of first estrus is similar to reports on

Table 1. Mean age, food intake, and body measurements at puberty in female rats ${ }^{1}$

\begin{tabular}{|c|c|c|c|c|c|c|}
\hline & \multicolumn{2}{|c|}{ Feed-restricted } & \multirow[b]{2}{*}{$P$} & \multirow{2}{*}{$\begin{array}{l}\text { Feed-restricted } \\
n=28\end{array}$} & \multirow{2}{*}{$\begin{array}{c}\text { Well fed (39) } \\
n=29\end{array}$} & \multirow[b]{2}{*}{$P$} \\
\hline & $\begin{array}{l}\text { Early maturers } \\
\qquad n=13\end{array}$ & $\begin{array}{l}\text { Late maturers } \\
\qquad n=13\end{array}$ & & & & \\
\hline \multicolumn{7}{|l|}{ At vaginal opening } \\
\hline Age, days & $44.2 \pm 1.24$ & $63.3 \pm 3.71$ & $<0.001$ & $53.7 \pm 2.51$ & $37.9 \pm 0.94$ & $<0.001$ \\
\hline Body wt (BW), g & $119.9 \pm 2.99$ & $153.7 \pm 3.71$ & $<0.001$ & $135.7 \pm 3.97$ & $135.3 \pm 3.99$ & NS \\
\hline Food intake (FI), g/day & $10.34 \pm 0.28$ & $11.1 \pm 0.32$ & NS & $10.57 \pm 0.42$ & $15.2 \pm 0.48$ & $<0.001$ \\
\hline FI/100 g BW/day, g & $8.67 \pm 0.28$ & $7.21 \pm 0.27$ & $<0.001$ & $7.88 \pm 0.33$ & $11.3 \pm 0.26$ & $<0.001$ \\
\hline \multicolumn{7}{|l|}{ At first estrus } \\
\hline Age, days & $46.2 \pm 1.34$ & $70.1 \pm 4.18$ & $<0.001$ & $57.8 \pm 2.99$ & $39.6 \pm 1.23$ & $<0.001$ \\
\hline $\mathrm{BW}, \mathrm{g}$ & $126.7 \pm 4.11$ & $167.0 \pm 3.97$ & $<0.001$ & $145.0 \pm 4.80$ & $143.3 \pm 5.79$ & NS \\
\hline Nose-rump length, cm & $15.5 \pm 0.19$ & $16.8 \pm 0.14$ & $<0.001$ & $16.1 \pm 0.17$ & $15.8 \pm 0.17$ & NS \\
\hline Total body water (TBW), g & $88.6 \pm 3.04$ & $109.3 \pm 2.21$ & $<0.001$ & $98.2 \pm 2.73$ & $94.6 \pm 2.83$ & NS \\
\hline TBW/BW, \% & $70.1 \pm 0.42$ & $65.8 \pm 0.70$ & $<0.001$ & $68.1 \pm 0.55$ & $66.9 \pm 0.48$ & NS \\
\hline Body fat, $\mathrm{g}$ & $7.9 \pm 0.78$ & $14.4 \pm 1.37$ & $<0.001$ & $10.8 \pm 0.97$ & $14.4 \pm 1.21$ & $<0.025$ \\
\hline \%Fat & $6.17 \pm 0.48$ & $8.52 \pm 0.69$ & $<0.01$ & $7.18 \pm 0.46$ & $9.9 \pm 0.47$ & $<0.001$ \\
\hline Body protein, $\mathrm{g}$ & $24.13 \pm 0.93$ & $32.27 \pm 1.32$ & $<0.001$ & $27.96 \pm 1.07$ & $25.05 \pm 0.97$ & $<0.05$ \\
\hline \%Protein & $18.9 \pm 0.42$ & $19.0 \pm 0.82$ & NS & $19.45 \pm 0.44$ & $17.6 \pm 0.29$ & $<0.001$ \\
\hline FI/day, g & $10.98 \pm 0.67$ & $11.63 \pm 0.44$ & NS & $11.1 \pm 0.61$ & $14.6 \pm 0.35$ & $<0.001$ \\
\hline $\mathrm{FI} / 100 \mathrm{~g} \mathrm{BW} /$ day, $\mathrm{g}$ & $8.6 \pm 0.31$ & $6.99 \pm 0.29$ & $<0.001$ & $7.75 \pm 0.37$ & $10.5 \pm 0.42$ & $<0.001$ \\
\hline
\end{tabular}

1 NS: not significant 
the unchanging proportion of lean body mass estimated for well fed girls (17) and directly measured in rats (39) at all pubertal ages. In rats, the proportion of body protein increases from birth to adult life (19). Since the lean body mass or body cell mass (an approximate measure of total body protein) is the major contributor to basal metabolism $(4,29)$ our finding of an invariant proportion of body protein at sexual maturation would be in accordance with the hypothesized metabolic level which, when reached, acts to signal pubertal onset $(17,27)$. The overall difference observed in percentage of protein between the well fed and the feed-restricted rats at sexual maturation does not reduce the importance of the attainment of a certain constant proportion of body protein within groups of pubertal animals. The relative usefulness of comparing average group data with individual within-group measurements has been discussed (38, 39). It is possible that the feed-restricted animals developed with an elevated or abnormal metabolism as the result of their stress-related dietary deprivation and/or the reduced proportion of metabolically inactive body fat. Thus the fall to the hypothesized average metabolic level critical for pubertal onset (17) occurred later and with a greater proportion of body protein than the well fed controls (Figure 2 and Table 1). Recent studies on well fed female rhesus monkeys (38), heifers (1), and ewes (12) show body weight to increase with age at puberty. A similar body composition, as seen in the presently studied rats (Figure 2 and Table 1) (39), may account for the differences in body weight observed within groups of pubertal monkeys and domestic animals. Furthermore, within samples of girls with varying proportions of estimated body fat or body weight at puberty $(2$, $5,8,15,31,35)$, the acquisition of similar percentages of body protein at sexual maturation may explain these differences in body composition and weight.

\section{CONCLUSION}

Body weights at birth, weaning, and puberty (vaginal opening and first estrus) and food intake, body length, and body composition at first estrus were measured in 28 feed-restricted rats and were compared to measurements in 29 well fed controls. At first estrus, on the average, although feed-restricted rats were older and leaner, and had acquired more body protein and consumed less food, they attained the same body weight, body water, and nose-rump length as the well fed animals. Within either the well fed or feed-restricted group at first estrus we found the late maturing animals had attained a greater noserump length, body weight, amount of body fat, protein, and water; they were proportionally fatter, and consumed a smaller amount of food per $100 \mathrm{~g}$ of body wt than the early maturers. Despite these differences in food intake and somatic measurements observed within both well fed and feed-restricted groups of pubertal rats, the proportion of body protein did not differ.

\section{REFERENCES AND NOTES}

1. Arije, G. E., and Wiltbank, J. N.: Age and weight at puberty in Hereford heifers. J. Anim. Sci., 33: 401 (1971).

2. Billewicz, W. Z., Fellowes, H. M. and Hytten, C. A.: Comments on the critical metabolic mass and the age of menarche. Ann. Hum. Biol., 3: 51 (1976).

3. Brown, J. B., and Strong, J. A.: The effect of nutritional status and thyroid function on the metabolism of oestradiol. J. Endocrinol., 32: 107 (1965).

4. Brožek, J., and Grande, F.: Body composition and basal metabolism in man: correlation analysis versus physiological approach. Human Biol., 27: 22 (1955).

5. Cameron, $\mathbf{N}$.: Weight and skinfold variation at menarche and the critical body weight hypothesis. Ann. Hum. Biol., 3: 279 (1976).

6. Cohn, C., and Joseph, D.: Changes in body composition attendant on force feeding. Am. J. Physiol. 196: 965 (1959).

7. Cohn, C., Joseph, D., Bell, L., and Allweiss, M. D.: Studies on the effects of feeding frequency and dietary composition on fat deposition. Ann. N. Y. Acad. Sci., 131: 507 (1965).

8. Crawford, J. D., and Osler, D. C.: Body composition at menarche: The Frisch-Revelle hypothesis revisited. Pediatrics, 56: 449 (1975).

9. Crichton, J. A., Aitken, J. N., and Boyne, A. W.: The effect of plane of nutrition during rearing on growth, production, reproduction and health of diary cattle. I. Growth at 24 months. Anim. Prod., 1: 145 (1959).

10. Dickerson, J. W. T., Gresham, G. A., and McCance, R. A.: The effect of undernutrition and rehabilitation on the development of the reproductive organs: pigs. J. Endocrinol., 29: 111 (1964).

11. Dreizen, S., Spirakis, C. N., and Stone, R. E.: A comparison of skeletal growth and maturation in undernourished and well-nourished girls before and after menarche. J. Pediatrics, 70: 256 (1967).

12. Dýrmundsson, $\mathbf{O}$. R., and Lees, J. L.: A note of factors affecting puberty in Clun Forest female lambs. Anim. Prod., 15: 311 (1972).

13. Frisch, R. E.: Weight at menarche: similarity for well-nourished and undernourished girls at differing ages and evidence for historical consistency. Pediatrics, 50: 445 (1972).

14. Frisch, R. E., Hegsted, D. M., and Yoshinaga, K.: Body weight and food intake at early estrus of rats on a high diet. Proc. Natl. Acad. Sci. U. S. A. 72: 4172 (1975).

15. Frisch, R. E., and McArthur, J.: Menstrual cycles: Fatness as a determinan of minimal weight for height necessary for their maintenance or onset. Science, 185: 949 (1974).

16. Frisch, R. E., and Revelle, R.: Height and weight at menarche and a hypothesis of critical body weights and adolescent events. Science, 169: 397 (1970).

17. Frisch, R. E., Revelle, R., and Cook, S.: Components of the critical weight at menarche and at initiation of the adolescent spurt: estimated total water. lean body mass and fat. Human Biol., 45: 469 (1973).

18. Gallegos, A. J., and Cannales, E. S.: In vitro estrogenic production by human mammary gland. Endocrine Society: Program of 51st Meeting. New York. Abstract 99, p. 80 (1969).

19. Hatai, S.: Changes in the composition of the entire body of the albino rat during the life span. Amer. J. Anat., 21: 23 (1917).

20. Hayes, K. C., Rabin, A. R., and Berson, E. L.: An ultrastructural study of nutritionally induced retinal degeneration in cats. Amer. J. Path., 78: 505 (1975).

21. Hegsted, D. M.. Gallagher, A., and Hanford, H.: Inositol requirement of the gerbil. J. Nutr., 104: 588 (1974).

22. Hegsted, D. M., Gallagher, A., and Hanford, H.: Reducing diets in rats. Amer. J. Clin. Nutr., 28: 837 (1975).

23. Hervey, G. R.: Regulation of energy balance. Nature, 222: 629 (1969).

24. Hervey, G. R.: Physiological mechanisms for the regulation of energy balance. Proc. Nutr. Soc., 30: 109 (1971).

25. Joubert, D. M.: Puberty in female farm animals. Anim. Breeding Abs., 31: 295 (1963)

26. Kennedy, G. C.: Role of depot fat in the hypothalamic control of food intake in the rat. Proc. Roy. Soc. B, 140: 578 (1953).

27. Kennedy, G. C., and Mitra, J.: Body weight and food intake as initiating factors for puberty in the rat. J. Physiol., 166: 408 (1963).

28. Monteiro, L. S., and Falconer, D. S.: Compensatory growth and sexual maturity in mice. Anim. Prod., 8: 179 (1966).

29. Moore, F. D., Oleson, K. H., McMurrey, J. D., Parker, H. V., Ball, M. R. and Boyden, C. M.: The Body Cell Mass and Its Supporting Environment: Body Composition in Health and Disease (W. B. Saunders Company, Philadelphia, 1963).

30. Nimrod, A., and Ryan, K. J.: Aromatization of androgens by human abdominal and breast fat tissue. J. Clin. Endocrinol. Metab., 40: 367 (1975).

31. Osler, D. C., and Crawford, J. D.: Examination of the hypothesis of a critical weight at menarche in ambulatory and bedridden mentally retarded girls. Pediatrics, 51: 657 (1973).

32. Shindler, A. E., Ebert, A., and Friedrich, E.: Conversion of androstenedione to estrone by human fat tissue. J. Clin. Endocrinol. Metab., 35: 627 (1972).

33. Snedecor, G. W., and Cochran, W. G.: Statistical Methods. Ed. 6 (Iowa State University Press, Ames, lowa, 1967).

34. Tanner, J. M.: Growth at Adolescence, Ed. 2 (Blackwell Scientific Publications, Oxford, 1962)

35. Welon, Z., and Bielicki, T.: The adolescent growth spurt and the "critical body weight" hypothesis. Mater. Prace Anthropol., 86: 27 (1973).

36. Widdowson, E. M., and McCance, R. A.: Some effects of accelerating growth. I. General somatic development. Proc. Roy. Soc. Ser. B Biol. Sci., 152: $188(1960)$.

37. Widdowson, E. M., Mavor, W. O., and McCance, R. A.: Effect of undernutrition and rehabilitation on the development of the reproductive organs: rats. J. Endocrinol., 29: 119 (1964).

38. Wilen, R., and Naftolin, F.: Age, weight and weight gain in the individual pubertal female rhesus monkey (Macaca mulatta). Biol. Reprod., 15: 356 (1976).

39. Wilen, R., and Naftolin, F.: Pubertal food intake, body length, weight and composition in the well fed female rat. Pediat. Res., 11: 701 (1977).

40. Williams, J. P. G., Tanner, J. M., and Hughes, P. C. R.: Catch-up growth in female rats after growth retardation during the suckling period: comparison with males. Pediat. Res., 8: 157 (1974).

41. Zacharias, L., Rand, W. M., and Wurtman, R. J.: A prospective study of sexual development and growth in American girls: the statistics of menarche. Obstet. Gynecol. Surv., 31: 325 (1976).

42. This diet contained casein $20 \%$, starch $70.3 \%$, fat (hydrogenated vegetable oil (Spry), Lever Brothers, New York) 5\%, vitamin mix $0.5 \%(21)$, salt mix $4 \%(20)$, choline chloride $0.2 \%$. 
43. We are grateful to Mr. John Wyse for assistance with the statistical analysis and to Mrs. Elaine Waddington for her help in preparing the manuscript.

44. This research was supported by funds from the Department of Anthropology, Harvard University, Fraser Foundation Research Funds, and a Medical Research Council of Canada grant to Professor F. Naftolin.

Copyright (C) 1978 International Pediatric Research Foundation, Inc $0031-3998 / 78 / 1204-0263 \$ 02.00 / 0$
45. Requests for reprints should be addressed to: Dr. H. Richard Wilen, Royal Victoria Hospital, Women's Pavilion, 687 Pine Avenue West, Montreal, Quebec, H3A 1 A1 (Canada).

46. Received for publication April 14, 1977.

47. Accepted for publication July 13, 1977.

Printed in U.S.A 